\title{
ANALISIS DHAMAN (GANTI RUGI) BAGI NASABAH WANPRESTASI DALAM PERBANKAN SYARIAH (Study Pada Pembiayaan Murabahah)
}

\author{
Siti Hayati* \\ *Fakultas Ilmu Agama Islam Universitas Islam Indonesia Yogyakarta \\ e-mail: Shayati070@gmail.com
}

\begin{abstract}
Abstrak: Sektor perbankan syariah di Indonesia terus menunjukkan perkembangan yang pesat. Hingga kini jenis pembiayaan perbankan syariah masih didominasi oleh prinsip jual beli dengan akad murabahah yang diketahui sangat minim resiko, namun tidak menutup kemungkinan gagal bayar atau wanprestasi dapat dihindari. Salah satu bentuk perlindungan dalam syariat Islam terhadap wanprestasi adalah adanya mekanisme dhaman (pemberian ganti rugi) kepada pihak yang hak-haknya dilanggar. Penelitian ini menggunakan metode deskriptif kualitatif dengan pendekatan sejarah dengan sumber data kepustakaan. Hasil penelitian ini menyatakan bahwa bank berhak memberikan sanksi kepada nasabah yang terbukti mampu bayar namun melakukan tunggakan atas pembayaran angsuran dan/atau wanprestasi atas setiap ketentuan yang telah disepakati dalam kontrak. Sanksi yang dapat diterapkan adalah berupa denda (ta'zir) dan/atau ganti rugi (dhaman). Bank dapat menerapkan salah satu atau keduanya kepada nasabah wanprestasi, dan tidak langsung serta merta diadakannya penyitaan atau pelelangan barang angunan, namun sebelum itu pihak bank syariah terlebih dahulu menawarkan restrukturisasi kepada nasabah. Namun kalau memang nasabahnya dengan sengaja memanfaatkan kondisi seperti ini, maka pihak bank syariah dapat mengenakan sanksi berupa ganti rugi kepada nasabahnya. Terkait beberapa ketentuan mengenai ganti rugi ini telah ditatur dalam Fatwa Dewan Syariah Nasional MUI Nomor: 43/DSN-MUI/VIII/2004 tentang Ganti Rugi (dhaman).
\end{abstract}

Kata kunci: Murabahah, Wanprestasi, Ganti Rugi, Perbankan Syariah 


\section{PENDAHULUAN}

Indonesia merupakan salah satu negara dengan penduduk Muslim terbesar di dunia. Hal ini merupakan salah satu faktor pendorong meningkatnya kinerja industri syariah termasuk didalamnya perbankan syariah. Secara umum jenis pembiayaan pada bank syariah terbagi dalam tiga prinsip, yaitu prinsip bagi hasil, sewa-menyewa atau jasa, dan prinsip jual beli yang menggunakan akad seperti murabahah, salam, istishna. Sampai saat ini jenis pembiayaan perbankan syariah masih didominasi oleh prinsip jual beli dengan akad murabahah khususnya hal ini disebabkan oleh beberapa faktor, dari sisi penawaran bank syariah pembiayaan murabahah dinilai lebih minim resikonya dibandingkan dengan jenis pembiayaan bagi hasil. Selain itu pengembalian yang telah ditentukan sejak awal juga memudahkan bank syariah dalam memprediksi keuntungan yang akan diperoleh (Yaya et.al, 2014:160).

Adanya penyaluran dana dengan jumlah besar, tidak dapat dipungkiri hal tersebut akan menimbulkan resiko terkait dengan pengembalian dana modal yang digunakan oleh entitas tersebut. Gagal bayar atau wanprestasi merupakan resiko yang dialami bank syariah dalam melakukan pembiayaan, yang mana resiko tersebut harus diminimalisir demi mendapatkan keuntungan yang maksimal. Adapun akibat dari wanprestasi itu biasanya dapat dikenakan sanksi ganti, pembatalan kontrak, peralihan resiko, maupun membayar biaya perkaranya.

Hal ini tentunya sangat kontradiktif dengan syariah Islam yang sangat melindungi kepentingan semua pihak yang bertransaksi, baik untuk lembaga keuangan syariah maupun nasabah, sehingga tidak boleh ada satupun pihak yang dirugikan hakhaknya.

Istilah Dhaman merupakan bentuk ganti rugi atas biaya-biaya riil yang telah dikeluarkan oleh bank syariah karena terjadinya proses perpanjangan pembayaran atau restrukturisasi yang diakibatkan karena cidera janji (wanprestasi) yang dilakukan nasabah. Restrukturisasi pembiayaan hanya boleh dikenakan atas kondisi nasabah yang mengalami penurunan kemampuan pembayaran kemudian terdapat sumber pembayaran angsuran yang jelas dari nasabah dan mampu memenuhi kewajiban setelah restrukturisasi.

Konsep dhaman berbeda dengan ta'zir, walaupun prosesnya terjadi karena adanya kesamaan, yaitu sama-sama karena kelalaian dengan menunda-nunda pembayaran. Dalam ta"zir (denda) dana yang dikumpulkan tersebut masuk ke dalam dana sosial, dan biasanya sudah ada dalam perjanjian dan besarnya pun telah ditentukan bukan karena kasus force majeur. Sedangkan dhaman (ganti rugi) dananya masuk sebagai pendapatan bank dan besarannya pun ditentukan sesuai dengan kerugian riilnya serta bukan karena kehilangan kesempatan atau time value of money. Adapun fatwa yang mengatur kedua hal ini pun berbeda, untuk ta'zir diatur dalam fatwa MUI nomor 17 tahun 2000 Tentang Sanksi Ta'zir, berdasarkan fatwa tersebut, nasabah yang lalai bisa dikenakan denda atau ta"zir. Sedangkan untuk dhaman diatur dalam Fatwa No.43/DSNMUI/VIII/2004 Tentang Ganti Rugi (Dhaman).

Dhaman atau ganti rugi ini memberikan pembelajaran kepada nasabah pembiayaan yang nakal, serta dapat membantu bank syariah untuk mendorong nasabah agar melunasi kewajibannya tepat waktu. Karena 
apabila perpanjangan pembayaran atau jatuh tempo terjadi, hal ini akan berdampak kepada penurunan kolektibilitas, sehingga pencadangan penghapusan aktiva produktif akan meningkat. Melalui latar belakang di atas, penulis tertarik untuk mengetahui lebih jauh mengenai proses dhaman dalam bank syariah, khususnya dalam pembiayaan murabahah.

\section{TINJAUAN PUSTAKA Murabahah}

Murabahah adalah akad jual beli barang dengan harga jual sebesar biaya perolehan ditambah keuntungan yang disepakati dan penjual harus mengungkapkan biaya perolehan barang tersebut kepada pembeli. Definisi ini menunjukkan bahwa transaksi murabahah tidak harus dalam bentuk pembiayaan tangguh (kredit), melainkan dapat juga dalam bentuk tunai setelah menerima barang, ditangguhkan dengan mencicil setelah menerima barang, ataupun ditangguhkan dengan membayar sekaligus dikemudian hari ((Yaya et.al, 2014:160).

\section{Wanprestasi}

Wanprestasi berasal dari bahasa Belanda, yang artinya prestasi buruk. Adapun yang dimaksud dengan wanprestasi adalah suatu keadaaan yang dikarenakan kelalaian atau kesalahannya, debitur tidak dapat memenuhi prestasi yang telah ditentukan dalam perjanjian dan bukan dalam keadaan memaksa (Salim, 2006:99).

Wanprestasi disebabkan oleh beberapa faktor antara lain dari sisi debitur yaitu adanya itikad tidak baik, menurunnya usaha debitur, pengelolaan usaha yang kurang baik, dan penggunaan pembiayaan yang kurang dengan tujuan semula.

\section{Ganti Rugi (Dhaman)}

Secara etimologis, dhaman memiliki makna yang cukup beragam, seperti menanggung, tanggung jawab, dan kewajiban. Dalam kamus Lisan al'Arab, Ibnu Manzur menjelaskan bahwa semua makna dhaman terkonsentrasi pada jaminan, penanggungan atau garansi. Makna yang tak jauh berbeda juga ditemukan dalam kamus al-Muhith yang mengartikan dhaman dengan ganti rugi (Mth, 2007:97-120).

Dalam term fiqh, dhaman juga dimaknai beragam, Imam Ghazali misalnya memaknai dhaman dengan "luzumu rad al-syayy' awu badaluhu bil mitsli awu bil qimati (keharusan mengganti suatu barang dengan barang yang sama atau sepadan dengan nilai jualnya). Al-Hamawy pensyarah Kitab AlAsybah wa Al-Nazair karya Ibn Nujaim mengatakan bahwa dhaman adalah ibâratun an raddi misli al-hâlik awu qimatuhu (mengganti barang yang rusak dengan barang yang sama atau yang sepadan dengan nilai jualnya). Sedangkan as-Syaukani mengatakan bahwa dhaman adalah ibaratun an garamati al-tâlif (mengganti barang yang rusak).

\section{Fatwa Tentang Ganti Rugi (Dhaman)}

Penerapan Fatwa DSN-MUI No. 43/DSN-MUI/VIII/2004 Tentang Ganti Rugi, dalam hal ini terdapat beberapa ketentuan umum mengenai dhaman antara lain sebagai berikut:

a. Ganti rugi (dhaman) hanya boleh dikenakan atas pihak yang dengan sengaja atau karena kelalaian melakukan sesuatu yang menyimpang dari ketentuan akad dan menimbulakan kerugian pada pihak lain.

b. Kerugian yang dapat dikenakan dhaman sebagaimana dimaksud dalam ayat 1 adalah kerugian riil 
yang dapat diperhitungkan dengan jelas.

c. Kerugian riil sebagaimana yang dimaksud ayat 2 adalah biayabiaya riil yang dikeluarkan dalam rangka perhitungan hak yang seharusnya dibayarkan.

d. Besar ganti rugi (dhaman) adalah sesuai dengan nilai kerugian riil yang pasti dialami dalam transaksi tersebut dan bukan kerugian yang diperkirakan akan terjadi karena adanya peluang yang hilang (opportunity loss atau al-furshah al-dha-I'ah).

e. Ganti rugi (dhaman) hanya boleh dikenakan pada transaksi (akad) yang menimbulkan utang piutang (dain), seperti Salam, Istishna, serta Murabahah dan Ijarah.

f. Dalam akad Mudharabah dan Musyarakah, ganti rugi hanya boleh dikenakan oleh shahibul maal atau salah satu pihak dalam Musyarakah apabila bagian keuntungannya sudah jelas tetapi tidak dibayarkan (Umam, 2016: 224-225).

Selanjutnya beberapa ketentuan khusus terkait dhaman antara lain:

a. Ganti rugi yang diterima dalam transaksi di lembaga keuangan syariah dapat diakui sebagai hak (pendapatan) bagi pihak yang menerimanya.

b. Jumlah ganti rugi besarnya harus tetap sesuai dengan kerugian riil dan tata cara pembayarannya tergantung kesepakatan para pihak.

c. Besarnya ganti rugi ini tidak boleh dicantumkan dalam akad.

d. Pihak yang cedera janji bertanggung jawab atas biaya perkara dan biaya lainnya yang timbul akibat proses penyelesaian perkara.

Dalam Fatwa DSN-MUI No.43/DSN MUI/VIII/2004 Tentang Ganti Rugi (dhaman) menyebutkan bahwa besaran ganti rugi hanya dapat dikenakan sesuai dengan nilai kerugian riil (real loss) yang pasti dialami dalam transaksi tersebut dan bukan kerugian yang diperkirakan akan terjadi (potential loss) karena adanya peluang yang hilang (opportunity loss atau alfurshah adh-dhai"ah).

\section{METODE}

Penelitian ini menggunakan metode deskriptif - kualitatif dengan pendekatan sejarah dengan sumber data kepustakaan. Kajian ini akan mengkaji lebih jauh tentang penerapan dhaman yang terdapat didalam pembiayaan murahabah pada perbankan syariah.

\section{PEMBAHASAN}

Bank dapat memberikan sanksi kepada nasabah yang terbukti mampu bayar namun melakukan tunggakan atas pembayaran angsuran dan / atau wanprestasi atas setiap ketentuan yang telah disepakati dalam kontrak. Sanksi yang dapat diterapkan adalah berupa denda (ta'zir) dan/atau ganti rugi (dhaman) dalam hal ini bank syariah dapat menerapkan salah satu atau keduanya.

Denda atas tunggakan (ta'zir) harus diperuntukkan sebagai dana sosial atau dana kebajikan, sementara ganti rugi (dhaman) dapat diakui sebagai pendapatan dalam pembukuan bank syariah. Denda atas tunggakan (ta'zir) hanya dikenakan kepada nasabah jika nasabah terbukti lalai atas kewajiban pembayaran angsurannya. Kelalaian nasabah didefinisikan sebagai kesalahan yang dilakukan oleh nasabah dalam hal 
keterlambatan pembayaran atas pembiayaan yang diberikan.

Kepada nasabah wanprestasi, pihak bank syariah tidak langsung serta merta melakukan penyitaan atau pelelangan barang agunan. Namun pihak bank syariah terlebih dahulu memanggil nasabah yang melakukan wanprestasi untuk dimintai keterangan terkait sebab nasabah tidak melakukan pembayaran kewajiban. Jika dalam hal ini nasabah masih mempunyai itikad baik, maka pihak bank syariah akan menawarkan kebijakan restrukturasi atau perpanjangan jangka waktu pembayaran kepada nasabah. Sehingga dalam hal ini pihak nasabah masih dapat memenuhi konsekuensi dalam memenuhi kewajibannya terhadap bank syariah.

Dalam kebijakan restrukturisasi pada pembiyaan murabahah, nasabah bank syariah tidak boleh dikenakan sanksi berupa late or default payment, hal ini karena transaksi murabahah merupakan transaksi syariah yang berdasarkan pada jual beli, bukan berupa pinjaman dengan imbalan bunga. Namun jikalau memang diketahui nasabahnya dengan sengaja memanfaatkan kondisi seperti ini, maka pihak bank syariah dapat mengenakan sanksi berupa ganti rugi terhadap nasabah tersebut.

Otoritas Jasa Keuangan pada tahun 2016 telah menetapkan beberapa standar ketentuan terkait pembebanan ganti rugi (dhaman) pada produk murabahah kepada nasabah yaitu:

1. Ganti rugi dikenakan kepada nasabah yang memang sengaja atau karena lalai melakukan sesuatu yang menyimpang dari akad dan mengakibatkan kerugian pada Bank.

2. Besarnya ganti rugi yang dapat diakui sebagai pendapatan bank adalah sesuai dengan kerugian riil (real loss) dan bukan kerugian yang diperkirakan akan terjadi (potential loss).

3. Bank hanya dapat mengenakan ganti rugi pada keuntungan bank yang sudah jelas tidak dibayarkan oleh nasabah.

4. Klausul ganti rugi harus ditetapkan secara jelas dalam akad dan dipahami oleh nasabah.

5. Penetapan ganti rugi atas kerugian riil ditetapkan berdasarkan kesepakatan antara bank dan nasabah.

Dalam penerapan dhaman pihak bank syariah menetapkan kebijakankebijakan yang telah sesuai dengan syariat Islam. Akan tetapi dalam menetapan ganti rugi perbankan syariah menggunakan kebijakan yang cenderung memberikan kesulitan kepada nasabah, dimana di sisi lain biaya ganti rugi yang dikenakan kepada nasabah dapat dikatakan memberatkan pihak nasabah, karena dalam kasus nasabah yang mengalami force majour seharusnya nasabah tidak boleh dikenakan ganti rugi melainkan memberikan kemudahan bagi nasabah dalam menyelesaikan pembiayaannya.

Sesuai dengan firman Allah Swt dalam Surah Al-Baqarah ayat 280 yang berbunyi:

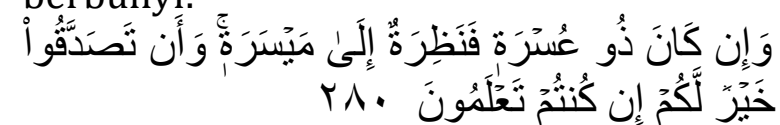

Artinya: "Dan jika (orang yang berhutang itu) dalam kesukaran, Maka berilah tangguh sampai Dia berkelapangan. Dan menyedekahkan (sebagian atau semua utang) itu, lebih baik bagimu, jika kamu mengetahui".

Ayat di atas memberikan makna bahwa jika ada pihak yang berhutang sedang dalam kesulitan, maka berilah ia tempo waktu sampai dia sanggup membayar hutangnya, dan sebaliknya bila 
yang berhutang dalam keadaan lapang, ia wajib segera membayar hutangnya.

Persoalan yang menimpa nasabah mengharuskan membayar ganti rugi adalah menurunnya kemampuan bayar nasabah. Hal ini tentunya sangat kontradiktif dengan syariah Islam yang sangat melindungi kepentingan semua pihak yang bertransaksi, baik lembaga keuangan syariah maupun nasabah, sehingga tidak boleh ada satupun pihak yang dirugikan hak-haknya.

Sehingga dapat diketahui bahwa ganti rugi hanya dapat dibebankan kepada debitur yang ingkar janji dan menimbulkan kerugian pada kreditur. Oleh karena itu, adanya aturan hukum ini sangat membantu untuk melindungi kepentingan pihak dimaksud (kreditur) dengan membebankan tanggung jawab untuk memberi ganti rugi atas pihak yang memungkiri janjinya (debitur).

\section{SIMPULAN}

Dari uraian yang telah dikemukakan di atas dapat disimpulkan bahwa, wanprestasi merupakan kasus yang umum dijumpai pada pembiayaan yang terdapat di perbankan syariah. Pada kasus seperti ini pihak bank syariah dapat memberikan sanksi kepada nasabah yang terbukti mampu bayar namun melakukan tunggakan atas pembayaran angsuran dan / atau wanprestasi atas setiap ketentuan yang telah disepakati dalam kontrak. Sanksi yang dapat diterapkan adalah berupa denda (ta'zir) dan/atau ganti rugi (dhaman). Bank dapat menerapkan salah satu atau keduanya. Untuk denda atas tunggakan ( $t a^{\prime} z i r$ ) harus diperuntukkan sebagai dana sosial atau dana kebajikansementara ganti rugi (dhaman) dapat diakui sebagai pendapatan dalam pembukuan bank.

Kemudian kepada nasabah yang telah melakukan wanprestasi pihak bank syariah akan melakukan pemanggilan kepada nasabah yang memiliki tunggakan untuk mengetahui alasan apa yang menyebabkan nasabah tersebut tidak memenuhi kewajibannya. Selanjutnya pihak bank syariah akan memberikan alternatif berupa kebijakan restrukturasi atau perpanjangan tempo pinjaman kepada nasabahnya hingga nasabah yang mengalami wanprestasi dapat melunasi kewajibannya.

Dalam hal restrukturisasi pembiayaan murabahah, nasabah bank syariah tidak boleh dikenakan sanksi late or default payment, karena transaksi murabahah adalah prinsip syariah berdasarkan jual beli, bukan pinjaman dengan imbalan bunga, beberapa ketentuan mengenai ganti rugi ini telah ditatur dalam Fatwa Dewan Syariah Nasional MUI Nomor: 43/DSN-MUI/VIII/2004 tentang Ganti Rugi (Dhaman).

\section{DAFTAR RUJUKAN}

Mth, Asmuni. (2007). Teori Ganti Rugi (Dhaman) Perspektif Hukum Islam. Millah Vol. 6 No. 2.

Salim H.S. (2006). Hukum Kontrak Teori dan Teknik Penyusunan Kontrak. Jakarta: Sinar Grafika.

Umam, Khotibul. (2016). Perbankan Syariah: Dasar- dasar dan Dinamika Perkembangannya. Jakarta: Rajawali Pers.

Yaya, Rizal, Aji Erlangga Martawireja, Ahim Abdurahim. (2014). Akuntansi Perbankan Syariah. Jakarta Selatan: Salemba Empat. 